\title{
A phenomenology study of using Instagram applications in personal creativity in photography at SMAN 2 Cirebon students
}

\author{
Isma Kharisma Zhuhriani ${ }^{\text {a,1,* }}$, Adinda Cinthia Fitrianas ${ }^{\text {b,2 }}$, Khalasa Shafira ${ }^{\text {b,3 }}$ \\ ${ }^{a}$ Universitas Muhammadiyah Cirebon \\ Prodi Ilmu Komunikasi Fakultas Ilmu Sosial dan Ilmu Politik, Jl. Tuparev No.70, Kedungjaya, Kedawung, Cirebon, Jawa Barat 45153 \\ ${ }^{1}$ kharismazhuhriani@gmail.com *; ${ }^{2}$ adindacf18@gmail.com; ${ }^{3}$ sakhalashafira@gmail.com \\ * corresponding author
}

Article history

Received 09-11-2021

Revised 10-11-2021

Accepted 11-11-202

Keywords

Qualitative Descriptive Study

Instagram, Photography

Self-Existence

\begin{abstract}
The development of communication technology today brings about a number of changes in human behavior. These changes include how to think, how to behave, and various other aspects. This study aims to identify the development of existence in adolescents today. With the development of online media, there are behavioral changes that are quite specific to individuals, especially in the way that individuals perceive or interpret themselves. Furthermore, currently there are applications such as Instagram that can display photos and videos, which depict individual self-images. Society, especially young people, among dynamic students, tend to be happy to express themselves through online media which are considered to increase their existence. In this paper, the research method used is a qualitative approach. The research subject was carried out on students of SMAN 2 Cirebon City. To collect data, the authors conducted interviews with informants. From the results of interviews and data collection, it was found that teenagers today like to use the Instagram application to share photos, such as selfies, food, and photography. Furthermore, the photos included in Instagram include photos of daily activities with their friends, in the form of selfies, including photography in the form of beautiful natural scenery.
\end{abstract}

This is an open access article under the CC-BY-SA license.

\section{Introduction}

Today, technological developments that have created the emergence of online media have influenced many aspects of life. The aspect of life that is greatly influenced by online media is the aspect of communication in today's society. One of the aspects of communication that attracts the attention of the author is intrapersonal communication. Intrapersonal communication is the use of language or thoughts that occur within the communicator himself. With the active internal involvement of the individual, it encourages someone to increase personal awareness (self awareness) has several elements that refer to the specific identity of the individual, one of which is the self-concept in which there is also a process of self-esteem (Fadillah \& Jandevi, 2020).

Self-concept is an individual's view of who the individual is, and it can be obtained through information provided by information given to individuals by others (Aharon et al., 2020). By knowing the individual self, one can also see the existence of oneself in him. Where existence can be defined as being. That existence arises because of awareness of the existence of something or someone. The notion of existence which indicates that a person exists, makes it interesting for the writer to study. The form of the existence that the writer means is proving one's existence through the use of online media, especially Instagram. With advances in technology and the situation of life 
today is developing very rapidly with the emergence of internet technology which then continues with the emergence of online media. The Internet has its own technology, mode of use, scope of service, content and image. The Internet is not owned, controlled or managed by a single body but is a network of computers connected intentionally and operates according to a mutually agreed protocol. A number of organizations, especially providers and telecommunication bodies, play a role in internet operations (McQuail \& Windahl, 2015).

As with technological developments, with online media, communication has also developed. Currently, communication is not only concerned with the real or reality area, but communication also reaches the virtual or virtual world. In Indonesia, social networking is booming. In the internet we are familiar with social networks, and even the latest one to emerge is Instagram. One of the online media that currently has a rapidly growing number of users. Instagram is an online media with the largest increase in the number of active users in the last six months at the beginning of 2014. Instagram is a photo sharing application that allows users to take photos, apply digital filters, and share them on various social networking services, including Instagram itself. One unique feature on Instagram is that it cuts the photo into a square shape, so it looks like the result of a Kodak Instamatic and Polaroid camer (Sloan et al., 2017).

The need for Instagram demands someone as a need to perpetuate themselves through a photo documentation with a description. This need will continue to increase when followed by various desires to exist or present one's identity in the midst of the environment. This also relates to selfexistence and how a person wants to show their self-image in online media (Instagram).

\section{Theorotocal Framework}

\section{a) Instagram}

Burbn, Inc. founded in 2010, a technology startup company that only focuses on developing applications for mobile phones. At first Burbn, Inc. itself has too much focus on mobile HTML5, but the two CEOs, Kevin Systrom and Mike Krieger decided to focus more on one thing only. After a week of trying to come up with a good idea, in the end they made the first version of Burbn, but it still contained some things that weren't perfect. The final version of Burbn, an application that can be used by the iPhone which contains too many features. It was difficult for Kevin Systrom and Mike Krieger to reduce the existing features, and start over, but in the end they only focused on the photos, comments, and also the ability to like a photo. That's what ultimately became Instagram (Sloan et al., 2017).

Instagram comes from the understanding of the overall functions of this application. The word "insta" comes from the word "instant", like a Polaroid camera which in its time was better known as "instant photo". Instagram can also display photos instantly, like a polaroid in appearance. Meanwhile, the word "gram" comes from the word "telegram" which is how it works to send information to other people quickly. Likewise, Instagram can upload photos using the Internet network, so that the information you want to convey can be received quickly. That's why Instagram is a substitute for instant and telegram (Annisa, 2021).

On April 9, 2012, it was announced that Instagram would be taken over by Facebook for nearly \$ 1 billion in cash and stock. On May 11, 2016, Instagram introduced a new look as well as new icons and new app designs. Inspired by the previous app icon, the new icon represents a simple camera and a vivid rainbow in gradient shape.

Instagram features, namely: Followers, The social system in Instagram is to follow other user accounts, or have Instagram followers. Thus communication between fellow Instagram users can be established by giving likes and also commenting on photos that have been uploaded by other users. Uploading Photos, The main use of Instagram is as a place to upload and share photos to other users. The photos that you want to upload can be obtained through the iDevice camera or photos in the photo album on the iDevice. Camera, Photos that have been taken through the Instagram application can be stored in the iDevice. Photo effects, In the initial version, Instagram has 15 photo effects that can be used by users when they want to edit their photos. These effects include: X-Pro II, Lomo-fi, Earlybird, Sutro, Toaster, Brannan, Inkwell, Walden, Hefe, Apollo, Poprockeet, Nashville, Gotham, 
1977, and Lord Kelvin. On September 20, 2011, Instagam has added 4 new effects, namely Valencia, Amaro, Rise, Hudson, and removing 3 effects, Apollo, Poprockeet, and Gotham. In applying effects, users can also remove photo frames that are included in the effect. Photo title, After the photo is edited, the photo will be taken to the next page, and the photo will be uploaded to Instagram or other social networks. Arroba, Like Twitter and Facebook, Instagram also has a feature that users can use to offend other users by adding an arroba sign (@) and entering the name of the user's Instagram account. Photo label, A label in Instagram is a code that makes it easy for users to search for the photo using "keywords". Competition, as a medium for uploading photos, one of the uses of Instagram is as a photography competition. In this competition, competition organizers use a label tag to indicate that the photo that has been uploaded has participated in the competition. Geotagging, After entering the photo title, the next section is the Geotag section. This section will appear when iDevice users activate their GPS on their iDevice. Thus the iDevice can detect the location of the Instagram users. Geotagging itself is the identification of geographic metadata on websites or photos. Social networks, in sharing photos, users can not only share them on Instagram, but they can also be shared via other social networks such as Facebook, Twitter, Foursquare, Tumblr, and Flickr which are available on the Instagram page to share these photos. Like sign, Instagram also has a like sign feature whose function is similar to that provided by Facebook, namely as a sign that other users like the photos that have been uploaded. Based on the length of time and the number of likes on a photo on Instagram, these are the specific factors that influence whether the photo is famous or not. But the number of followers is also an important element in making a photo famous. When a photo becomes famous, it will directly enter the popular page itself. Popular, when a photo entered into the popular page, which is a collection of popular photos from all over the world at that time (Djafarova \& Rushworth, 2017).

\section{b) Photography}

Understanding Photography is the art or process of producing images and light on film. It is true, if you are looking for an understanding of photography, the answer is almost the same, namely the process of painting using light media. But the most important thing is how to explore the art of photography. Photography is an activity or process of producing an image / photo art through light media with a device called a camera with a specific purpose and purpose (Hoelscher, 2016).

\section{Method}

This research was conducted using a phenomenological qualitative method. Research with a phenomenological approach seeks to understand the meaning of various events and human interactions in specific situations. (Valunaite Oleskeviciene \& Sliogeriene, 2020) explain that the phenomenological approach emphasizes various aspects of the subject of human behavior in order to understand how and what meaning they form from their daily events.

\section{Results and Discussion}

Data collection activities by asking questions to 2 respondents which include: male and female gender, active Instagram users, how often to use Instagram, the length of time using Instagram, activities when using Instagram, the number of Instagram followers, intensity of uploading selfie photos, and reasons for using Instagram (Sloan et al., 2017).

The following is an explanation of the perceptions of teenagers of SMAN 2 Cirebon using a phenomenological approach, namely about the use of the Instagram application on photographic creativity. The results of the interview are as follows:

"I am a student in grade 11 of Senior High School (SMA). I am an active user of an Instagram account in a day I can open the Instagram application up to 5 times or maybe more. Starting to have an Instagram account in 2016, the name of my Instagram account often changes if now my Instagram account name is @ rivaldy.noval. The number of my Instagram followers hasn't reached much, but only 400. In my opinion, Instagram has many benefits. Although, initially I created an Instagram account just because I was curious about the use of the Instagram application itself. However, now I know what are the benefits of Instagram. Among them, namely: First, to find 
various kinds of information, if I myself often look for information about news that is viral and to find out someone whether it's a famous person or just someone I want to find out myself. Second, to add friends, and for members to know about our daily life or the activities we are doing through photos uploaded to an Instagram account or only in instastory. Third, to find a photographic reference yourself. On my Instagram account, I have a certain concept or theme. I, often and prefer to upload photos of the atmosphere when traveling. But in uploading photos, I don't do it too often, because it depends on my traveling time. Although I like to take pictures of any atmosphere but I really choose what photos I will upload on my Instagram account, which I think are photos worthy of sharing with my people or followers on Instagram. So, I will upload it on my Instagram account. So, there is no specific time for me to upload photos on Instagram at least. Followers for me are very influential on the results I share, and it will make me famous "(Achmad Noval Rivaldy, Interview 18 July 2018).

"Having an Instagram account is almost 3 years mid-2015, I started to create an Instagram account. Now I have 2 accounts. The first account is my active account whose name is @i_adiynanfath and the second account is only to find out people are secret, only I know their names. The number of my Instagram followers hasn't reached 1000, but around 700, it's balanced with the following. There is no specific reason why I create an Instagram account except following the times. Because, almost all of my classmates have Instagram accounts. I opened the Instagram application in a day that can't be counted like it. I think Instagram has both a negative and a positive side. The positive thing about Instagram has several benefits for me personally, namely: for entertainment, making friends, information, and much more. The Instagram that I like and look for the most, is quotes or wise words. Even though I often open the Instagram application in a day, I don't upload photos on my Instagram account very often. At most 5 times a month I upload photos on my Instagram account. Even then, the photo I uploaded is random, with no specific theme. Because, for me, if the photo has a certain momentum and impression, I will share it on my Instagram account. For me, a photo shared by Instagram users must have its own meaning. That can be seen from the photos or captions they upload. " (Adiyana Fatih, Interview 18 July 2018).

Fig. 1. Display of informant's Instagram Account ( Source:https://instagram.com/rivaldy.noval/ \& https://instagram.com/i_adiynanfath/ )
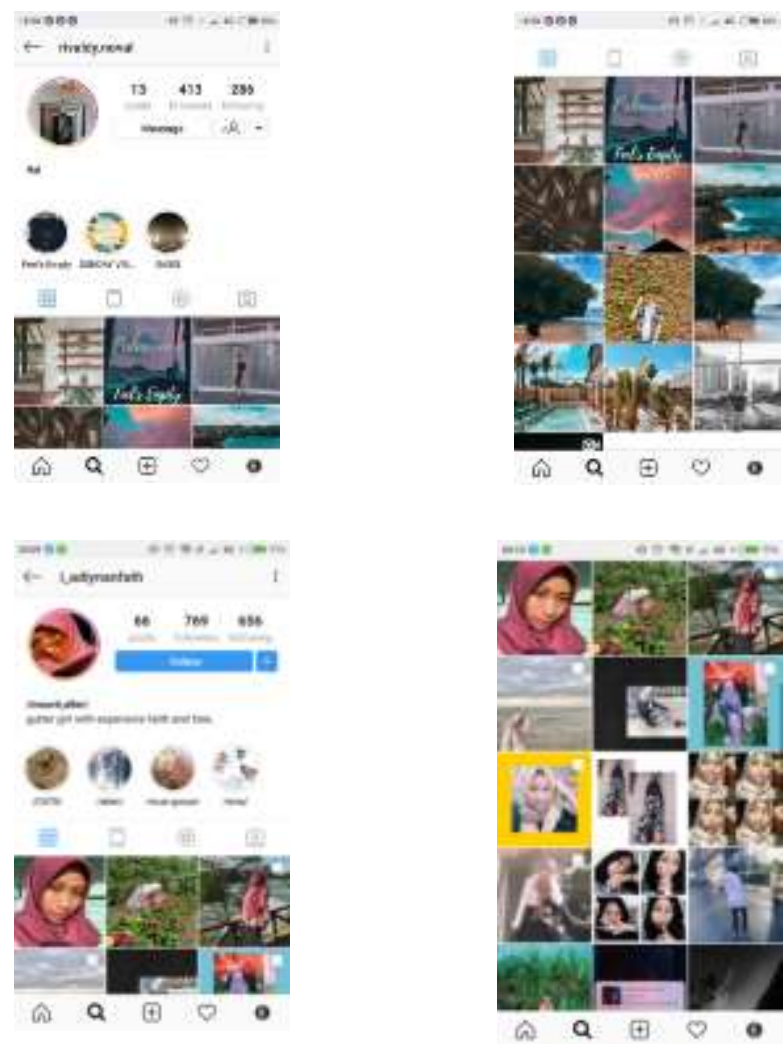

W: http://journal2.uad.ac.id/index.php/commicast/index |E: commicast@comm.uad.ac.id 
From the results of interviews and observations, researchers found Instagram to be used as a place or place for action to express themselves and show someone's personality by uploading them.

The number of followers of Achmad N.R's Instagram is around 413 and Adiyana has 769 accounts. Which is when a user uploads about nature and the atmosphere, he is someone who is calm and really likes art. And if he often uploads selfies it can indicate that he is someone who is confident. Today's Instagram favors where someone's upload has been shared and has gone viral, this is very easy to find on Instagram.

In one account with another account there can be different themes, because someone's creativity is different. A lot of passion when it comes to uploading a photo on Instagram. There are those who really intend to make Instagram as a medium to share their artwork, or share what and how these users like, and some are using Instagram as a medium to share whatever momentum is in their life. With this Instagram is a medium to share something that someone likes on a more positive side.

\section{Conclusion}

The conclusion in this study is that Instagram is one of the media for teenagers to develop their creativity in the art of photography. Instagram itself is intended to share someone's work, so that other users can see it. With this, Instagram has a positive side to the development of the digital era and the development of creativity of teenagers' ideas and works.

\section{References}

Aharon, L., Aharoni, S. L., Radisky, E. S., \& Papo, N. (2020). Supplementary Information for SUPPLEMENTARY INFORMATION. Biochemical Journal. https://doi.org/10.1038/NNANO.2015.70

Annisa, F. N. (2021). Konvergensi media pada perkembangan radio komersial di Yogyakarta (studi kasus pada radio Geronimo FM dan radio Swaragama FM). Commicast, 2(2), 90. https://doi.org/10.12928/commicast.v2i2.3350

Djafarova, E., \& Rushworth, C. (2017). Exploring the credibility of online celebrities' Instagram profiles in influencing the purchase decisions of young female users. Computers in Human Behavior. https://doi.org/10.1016/j.chb.2016.11.009

Fadillah, D., \& Jandevi, U. (2020). Media-social behavior of Muhammadiyah members in China in the framework of Alexander Wendt's international communication constructivism. Journal of Social Studies (JSS), 16(1), 51-64. https://doi.org/10.21831/jss.v16i1.34604

Hoelscher, S. (2016). Photography. In The Routledge Research Companion to Media Geography. https://doi.org/10.4324/9781315613178-6

McQuail, D., \& Windahl, S. (2015). Communication models: For the study of mass communications, second edition. In Communication Models for the Study of Mass Communications, Second Edition. https://doi.org/10.4324/9781315846378

Sloan, L., Quan-Haase, A., \& Laestadius, L. (2017). Instagram. In The SAGE Handbook of Social Media Research Methods. https://doi.org/10.4135/9781473983847.n34

Valunaite Oleskeviciene, G., \& Sliogeriene, J. (2020). Research methodology. In Numanities - Arts and Humanities in Progress. https://doi.org/10.1007/978-3-030-37727-4_2 